\title{
HISTORISKE FORBEMÆRKNINGER TIL REKONSTRUKTIONEN AF EN HEGEMONIAL MARXISME
}

\author{
Hans Jørgen Thomsen
}

\begin{abstract}
In any case, the absence among the radicalpopular forces of any awareness of the role of the other side prevented them from being fully aware of their own role either; hence from weighing in the final balance of forces in proportion to their effectice power of intervention; and hence from determining a more advanced result, on more progressive and modern lines.
\end{abstract}

Antonio Gramsci, 1933

Prison Notebooks, s. 113

\section{Den praktiske og teoretiske hypotese: det er (igen blevet) muligt at skabe en hegemonial historisk materialisme}

De følgende sider er et fors $\varnothing g$ på at argumentere historisk for overskriftens hypotese og ikke noget teoretisk fors $\emptyset \mathrm{g}$ på at indløse den. Det teoretiske eksperiment med at genskabe en kritisk historisk materialisme kan under alle omstændigheder kun foregå trinvist og i takt med, at den mulige fremtidige historie skaber indholdsmomenter i en sådan historisk materialisme i praksis. Hypotesen går ud på, at der i den nuværende historik-politiske situation kan anes muligheden af en sådan historisk materialisme - men heller ikke mere.

Dette sidste skal dog tages med et gran salt, eftersom der er en kerne af sandhed i Marx's programmatiske udsagn fra indledningen til Kritikken af den 
politiske økonomi fra 1857 om, at det kun er muligt at stille de spørgsmål i teorien, som historien allerede har sat på dagsordenen. Med andre ord: vi kan ikke skelne i nogen streng forstand mellem opridsningen af de historiske forudsætninger for en hegemonial marxisme og så den begyndende udfyldning af denne selv. De to momenter hænger sammen. Umiddelbart - dvs. personalt og bibliografisk (og ikke andet!) - kan de følgende sider derfor anskues som historiske selvreflektioner i kølvandet på et teoretisk arbejde, som jeg de sidste år har været involveret i sammen med tre andre personer: Jørgen Carlsen, LarsHenrik Schmidt og Hans-Jørgen Schanz. Det foreløbige resultat af dette arbejde er bogen om »Kapitalisme, behov og civilisation«, som er udgivet i foråret 1980 på forlaget Modtryk i Århus.

Dette arbejde har fået mig til at rejse nogle historiske og metodiske spørgsmål, som jeg ikke før har stillet mig. Samtidig har arbejdet på det nævnte historisk-teoretiske værk skabt et behov for at anskue det i et historisk perspektiv. Og da det historiske perspektiv altid også er fremtidshistorisk orienteret i en historisk materialisme, dvs. indrettet på at gennemtænke en eventuel anden fremtids muligheder og $» \mathrm{u}$-muligheder « $\mathrm{i}$ den givne situation - af dén grund opstod der også et behov for at fors øge at placere vores kollektive arbejdsproces $\mathrm{i}$ et politisk perspektiv. Altså et perspektiv, som relaterer sig til kampen om fremtiden; den kamp, som allerede er begyndt, og som synes at skulle foregå på nogle historisk nye og anderledes betingelser end tidligere $\mathrm{i}$ århundredet og i foregående århundrede. Som et led i kampen for en potentielt sandere fremtid hører kampen om hegemoni i teorien. Og det er betingelserne for et sådant muligt, fremtidigt hegemoni i teorien, som de følgende sider skal interessere sig for.

Før noget andet befinder disse betingelser sig i den historiske udvikling, og som muligheden for en genvinding af marxismens oprindeligt hegemoniale status overfor de borgerlige videnskaber og den borgerlige ideologi (nemlig i kritikken af den politiske $\varnothing$ konomi), er disse betingelser først ved at vikle sig ud af det sidste århundredes historie. Eller sagt omvendt: det sidste århundredes historie har for det første fravristet marxismen dens hegemoniale status, og for det andet har det i dette århundredes historie været objektivt umuligt for en marxistisk videnskabelighed at genvinde dette hegemoni. Det skal vi søge at vise i det følgende.

Først de sidste årtiers udvikling har langsomt løsnet op for historiens uheldssvangre kvælertag på den marxistiske videnskabelighed, og det er selvsagt sket samtidig med og sideløbende med, at historien selv har udviklet nye temaer, nye kampformer, nye alternativer. Det er disse, der muliggør, at de spørgsmål, som her forsøges stillet, overhovedet kan stilles. Men, men, men - foråret så 
sagte kommer. Og der står kamp om de nye betingelser, som ingenlunde er givne, men kun kan tilkæmpes i en stadig praktisk og teoretisk bevægelse. En bevægelse, som må være lige villig til at konstruere nye eksperimenter i teori og praksis, som den må være villig til at dekonstruere dem, når deres aktualitet og sandhed anfægtes i den virkelige historie.

Kun dialektikken mellem konstruktion og dekonstruktion, som korrellerer med historiens udvikling i brud og kontinuitet, kan MÅSKE gøre de antikapitalistiske bevægelser (fra fagbevægelsen til bøssebevægelsen) mere historisk potente end borgerskabets integrationseksperimenter. Hvis de antikapitalistiske bevægelser vil undgå det konstruktive element for at bevare kritikkens radikalitet, dømmer de sig selv til historisk impotens, og de kan integreres i visse dele af den borgerlige ideologis livstrætte insistering på opløsning og ikke andet. Hvis de omvendt kun vil dyrke det konstruktive element og fortrænge nødvendigheden af permanente dekonstruktioner (som er i tråd med den kapitalistiske histories egen bestandige relativering,) sker der udgrænsninger og dermed magtmæssige splittelser, som igen kan overlade det historiske initiativ til borgerskabet.

Betingelserne, som opsøges i det følgende, peger ikke i nogen som helst bestemt retning. De peger imidlertid, vil jeg hævde, på muligheder, som de antikapitalistiske bestræbelser KAN eksperimentere og konstruere videre på med henblik på at synliggøre et samfundsmæssigt alternativ til kapitalismen. Men modstanderen er også i bevægelse for at løse krisen, og han kan kun bremses i en modbevægelse. Og sker det ikke, må der nok ses frem til mindst endnu en generations liv på kapitalistiske betingelser, hvis besynderlighed og uegnethed for menneskelig tilværelse i dag kun kan anes.

Eet moment i modbevægelsen er rekonstruktionen af en kritisk historisk materialisme, og hertil hører skitseringen af denne historiske materialismes mulighedsbetingelser i historien selv. Det er til dette sidste, de følgende sider leverer et bidrag.

\section{Marxismens historie i det 19. og 20. århundrede. Et aktuelt anliggende}

(a) hvordan marxismen mister sit teoretiske hegemoni

I fors $\varnothing$ get på at rekonstruere en kritisk historisk materialisme står intet mere centralt $\mathrm{i}$ forarbejdet end rekonstruktionen af marxismens egen historie. 
Umiddelbart implicerer dette en nødvendig cirkelslutning, som dog ikke nødvendigvis behøver at blive til nogen ond cirkel, nemlig denne, at den kritiske historiske materialisme må grave i sin egen forhistorie, før den har sin egen metode.

Det er dog kun for en umiddelbar betragtning, at der hér er tale om et dilemma, eftersom det under alle omstændigheder er omsonst at ville forvente nogen Metode af marxismen. Metoden undgår aldrig at involvere sig med den beskidte historie, og den bliver aldrig til andet end regulative principper for dette uomgængelige livtag med den konkrete historie. Sandheden bliver aldrig til noget rent axiom i en - sand - historisk materialisme.

Fra starten svedes den marxske og den marxistiske videnskabelighed ud af historiens urene porer, og det undgår den ikke at bære præg af. Det skal den heller ikke undgå, eftersom den i sidste instans ikke er andet end forsøg på at tænke denne historie selv. Det betyder, at den marxske videnskab og marxismen er dybt involveret i dét borgerlige samfund, hvis kritiske selvreflektion de er. Klassemodsætningerne mellem borgerskab og proletariat er, som man véd, konstitutive for dette borgerlige samfund, og de er derfor også nødvendigvis konstitutive for den marxske videnskab og marxismen. Klassemodsætningerne vil altid eksistere i teorien, og det er, hvad Althusser kalder for en teoreticistisk fejltagelse at tro, at teorien nogensinde kan stå udenfor klassemodsætningerne og blot betragte disse (f.eks.).

Vi kan derfor roligt gå videre. Når klassemodsætningerne eksisterer i teorien, så betyder det, at teorien altid har et formidlet forhold til borgerlig videnskab på den ene side og arbejderklassens og arbejderbevægelsens erfaringer og historie på den anden side. Sådan har det altid været, og sådan er det den dag i dag. For Marx's og Engels' liv, altså deres fælles liv og arbejde (Engels' alderdom er et kapitel for sig selv), er sagen velkendt. På den ene side sveder klassekampene mellem det tidlige proletariat og borgerskabet fra starten det kritiske synspunkt ud, som Marx og Engels lægger ned over det borgerlige samfund. Og på den anden side udarbejdes synspunktet i en stadig og stædig kritisk bearbejdning af samtidens mest modne, videnskabelige resultater. Det drejer sig om den utopiske socialisme, det drejer sig om den tyske idealisme (Hegel) og det drejer sig frem for alt om den klassiske borgerlige $\varnothing$ konomi.

Dette vides efterhånden af enhver marxist, og jeg skal ikke hér gå nærmere i detaljer med alle de mange komplicerede detailspørgsmål, som denne sammenhæng kan afstedkomme. Er der et epistemologisk brud mellem den unge og den ældre Marx, hvordan er forholdet til Hegel i de forskellige faser etc., etc.? En del af disse spørgsmål kan anses for løst, og en del af dem vil nok aldrig blive det i teoriens »rene « form, fordi de igen og igen involveres i den aktuelle strid i teorien. Hvad angår revolutionsteorien i hele denne fase, skal 
det dog bemærkes, at Marx og Engels helt frem til pariserkommunen igen og igen forventer kapitalismens snarlige sammenbrud, og en del af deres revolutionsteoretiske overvejelser er ikke fri for at have et jakobinistisk tilsnit. Jakobinismens modsætning er dog også til stede, især i den marxske kritik af den politiske $\varnothing$ konomi, nemlig opfattelsen af at kapitalismen af sig selv fører frem til sit eget sammenbrud og dermed et nyt samfund. Der regnes i kritikken af den politiske $\emptyset$ konomi også med en kontinuitet mellem kapitalisme og socialisme, men det er stadig en kontinuitet, som fører frem til sammenbruddet pr. indre nødvendighed.

Det afgørende i denne fase er under alle omstændigheder den videnskabelige etablering af kritikken af den politiske $\varnothing$ konomi, altså den historiskkritiske begribelse af kapitalismens verdenshistoriske differentia specifica. Hér er den teoretiske hovedkilde til ethvert aktuelt forsøg på at rekonstruere en kritisk historisk materialisme. Da det imidlertid i sammenhængen hér ikke er denne altafgørende relation, som er emnet, kan vi lade det være godt med understregningen af kritikken af den politiske $\varnothing$ konomis helt afgørende centralitet $\mathrm{i}$ forbindelse med en aktuel rekonstruktion af en kritik historisk materialisme.

Men som man véd, skuffedes Marx og Engels - og især Marx - igen og igen over, at de tilbagevendende kriser i den kapitalistiske økonomi ikke førte til noget revolutionært brud med kapitalismen. Eet moment i dette håb om et endeligt sammenbrud, som ikke kan tillægges nogen umiddelbar videnskabelig værdi, er iøvrigt nok den marxske teori om, at den tiltagende elendighed for masserne i krise-situationen på et tidspunkt med nødvendighed ville føre frem til et revolutionært brud. Ligeså marginal denne elendighedsteori er placeret $\mathrm{i}$ kritikken af den politiske $\varnothing$ konomi, ligeså givet er det, at den ikke er sand. Dét har historien i det mindste vist, og sandheder imod eller på trods af historien er ikke den historiske materialismes sag. Det sande i elendighedsteorien er, at kapitalismens $\varnothing$ konomiske kriser fører til øget social elendighed for den brede befolkning (også dét har historien vist igen og igen), men det forkerte er antagelsen om, at øget social elendighed automatisk fører til noget revolutionært brud med kapitalismen.

Til gengæld viser kapitalismen i den sidste fjerdedel af det forrige århundrede nogle træk, som skal blive afgørende for udviklingen af den marxistiske videnskabelighed i de kommende år og er det den dag i dag. Ikke nok med, at de stadig genkommende kriser ikke fører til noget revolutionært brud med kapitalismen. Der er også momenter i kapitalismen, som betyder, at nok gentager krisemønstret og dets logik sig hele tiden eller med jævne mellemrum, men det er alligevel ikke de samme kriser, der gentager sig endnu engang. Kapitalismen indeholder sekulare udviklings- og 
fremskridtstendenser, som uafladeligt bringer den menneskelige civilisation (såvel i dennes åndelige som i dens materielle dimensioner) frem til nye stadier. Dette forhold reflekteres og anticiperes i rigt mål i den borgerlige videnskabelighed fra $1850 \mathrm{og}$ frem, og det er også blevet anticiperet f.eks. i borgerskabets historieforståelse siden oplysningstænkningens gennemslag i midten af det 18. århundrede.

Men det er ikke blot i den borgerlige videnskab, at civilisationsudviklingen i kølvandet på kapitalismens historie indoptages og iøvrigt misforstås. Arbejderklassen og arbejderbevægelsen indoptager også denne civilisationsudviklende dimension i sin teori og praksis efter nederlaget i pariserkommunen. Ja, forholdet til kapitalismens civilisationsudviklende potens bliver et helt afgørende punkt $\mathrm{i}$ arbejderbevægelsens teori og praksis fra den sidste fjerdedel af forrige århundrede og frem.

Marx når ikke at opleve dette $\mathrm{i}$ andet end meget vage former, men han når dog at kritisere det tyske socialdemokratis Gothaprogram. Dog uden at denne kritik får nogen som helst politisk betydning i samtiden, ja, den offentliggøres slet ikke. Engels derimod kaster sig med liv og sjæl ind i fortolkningen af disse nye udviklingstrends i kapitalismen, og det er hos Engels, at vi først kan se de teoretiske effekter af disse udviklingstrends på den marxistiske videnskabelighed. Den mest bastante ingrediens, som må integreres i teorien, er arbejderklassens og arbejderbevægelsens $\varnothing$ konomiske, sociale og politiske fremgangslinje i kølvandet på den kapitalistiske økonomis lange fremgangslinje. Det må konstateres og integreres i den marxistiske videnskabelighed, at arbejderklassen og arbejderbevægelsen kan tilkæmpe sig materiel og åndelig fremgang under kapitalismen. Kapitalisme er ikke længere umiddelbart identisk med den brede befolknings generelle vanskæbne. Tværtimod kan befolkningen tilkæmpe sig andele i kapitalismens civilisatoriske indhold og således opnå en fremgang under kapitalistiske produktionsprincipper, som igen kan sættes over styr - både af en radikalt undertrykkende kapitalisme, men også af en altfor-radikal og udemokratisk revolutionsproces. Det giver med andre ord ikke længere mening at slås for afskaffelsen af kapitalismen for enhver pris. Men lad os i første omgang koncentrere os om de teoretisk-videnskabelige effekter, sådan som vi kan aflæse dem hos den gamle Engels.

I takt med at arbejderklassen tilkæmper sig andele i kapitalismens civilisatoriske indhold, bliver det en påtrængende opgave for arbejderklassens teoretikere at give en selvstændig (proletarisk) fortolkning af dette forhold. Efter at klassekampen er overgået fra en »bevægelseskrig « (Gramsci), som blev tabt under pariserkommunen og kostede dyrt, til en »stillingskrig «(Gramsci), bliver det til en selvstændig teoretisk opgave at definere arbejderklassens og arbejderbevægelsens »stilling« i den nye situation. Proletariatet må definere 
sin egen kultur og verdensanskuelse, og det er nødvendigheden af dette, som fører til, at en mængde momenter i en autentisk kapitalismeforståelse, sådan som den foreligger i kritikken af den politiske økonomi, igen går tabt. Selv om altså den nye situation stiller en række nye krav til den marxistiske videnskabelighed, så betyder det ikke desto mindre, at indløsningerne af disse krav fører til en række fatale misforståelser i teorien og misgreb i politikken. De mest markante udtryk for dette er fors $\varnothing$ gene på at opstille en generaliseret teori om historien (den generaliserede historiske materialisme) og en generaliseret teori om naturen samt efterhånden også en generaliseret teori om den videnskabelige erkendelse af disse to faktorer (dét, der siden skulle blive til den dialektiske materialisme).

Sagt kort og kategorisk betyder det, at den marxistiske videnskabelighed overtager så godt som hele inventaret i den borgerlige videnskabs klassekampsmæssigt forståelige misfortolkninger af den nye situation. I takt med at arbejderbevægelsen bliver den eneste politiske arvtager af de borgerlige friheds- og lighedsideer, bliver dens teori desværre også den eneste arvtager af borgerskabets misforståelser af historiens udviklingsform og naturens beskaffenhed samt erkendelsen af disse.

Vi må fastholde det tvetydige i den nye situation. På den ene side er det politisk vigtigt og politisk forståeligt, at forsvaret af de borgerlige revolutioners demokratiske utopier nu bliver til arbejderklassens og arbejderbevægelsens sag. Borgerskabet opgiver og må opgive de demokratiske ideers radikale indhold for at forsvare sit klasseherredømme, medens arbejderklassen/arbejderbevægelsen begynder at give disse ideer et virkeligt historisk og konkret indhold. På den anden side viser det borgerlige samfunds integreringskraft sig hér overfor den marxistiske videnskabelighed. Denne taber i stadig højere grad sin kritiske differentieringskraft overfor det borgerlige samfunds historie, og det sker ved, at kategorierne generaliseres og ontologiseres, hvorved de fratages deres kritisk-utopiske potens. Jeg skal nøjes med at pege på dette rent stikordsagtigt, da alle eksemplerne hver for sig egentlig kræver vidtrækkende analyser. Arbejdsbegrebet generaliseres og ontologiseres i en generel teori om mennesket som et arbejdsomt væsen frem for alt, og derved tabes muligheden for utopiske differentieringer i arbejdsbegrebet. Side om side med at de arbejdsomme proletarer i den kapitalistiske storindustri skaber materielle forudsætninger for en udvikling af samfundsmæssiggørelsen, overtager proletariatets teoretikere den protestantiske etiks arbejdsmoralisme i bestræbelserne på at konstruere en ontologi med udgangspunkt i et generaliseret arbejdsbegreb. Derved glemmes det, at et udifferentieret arbejdsbegreb aldrig kan blive til noget hovedanliggende $\mathrm{i}$ en kritisk historisk materialisme, hvilket Marx havde slået fast i sin (oversete) Kritik af Gotha Programmet fra 1875. 
I historieteorien generaliseres der frem til en almen dialektik mellem produktivkræfter og produktionsforhold eller mellem basis og overbygning, og derved glemmes det, at sådanne almene historieteoretiske dialektikker er blevet videnskabeligt dementeret $\mathrm{i}$ kritikken af den politiske $\varnothing$ konomis fremstilling af kapitalismens differentia specifica. Da dette desværre aldrig er blevet udviklet konkret af og efter Marx, men blot ligger impliceret i selve kritikken af den politiske økonomis fremstilling, har det ikke været svært at drive denne type historieteoretiske generaliseringer frem. Så meget mere som også hele tidsånden i slutningen af forrige århundrede har været svanger med sådanne generaliseringer.

Endelig overtager marxismen i denne fase de borgerlige videnskabers intentioner om at skabe en generel teori om naturen og naturhistorien. I den proletariske verdensanskuelse bliver dette til naturdialektikken, som historisk er vigtigere ved de problematikker, som den tildækker, end de problematikker, som den eventuelt åbner op for og eventuelt også udsiger noget sandt om. Historisk tildækker naturdialektikken problematikken omkring bruddet mellem den første og den anden natur, og den anden natur underlægges tendentielt forståelsesskemaerne fra begribelsen af den første natur. Derved tabes muligheden for at tilegne sig samfundsmæssiggørelsens dobbeltkarakter, først og fremmest dette, at der er tale om en kapitalistisk form for samfundsmæssiggørelse og civilisering.

Dette sidste kan vi opsummere alle fejltagelserne i, som begås af den marxistiske videnskabeligheds udvikling i den sidste fjerdedel af det forrige århundrede. Fundamentalt overses det, at den stedfindende samfundsmæssiggørelse og civilisering, som arbejderklassen og arbejderbevægelsen også tilkæmper sig andele i, er en kapitalistisk form for samfundsmæssiggørelse og civilisering. En kapitalistisk form for samfundsmæssiggørelse og civilisering, som har en lang række unødvendige omkostninger målt med de muligheder for menneskeliggørelse, som historien allerede har skabt. Og denne fejlforståelse kommer arbejderklassen, arbejderbevægelsen og den marxistiske videnskabelighed til at betale meget dyrt for i det efterfølgende, tyvende århundrede.

Det er ikke til at sige, om denne udvikling kunne være undgået. Nok er det at konstatere, at sådan er gået, og bagkloge spekulationer om, hvordan det kunne være forløbet er ikke en kritisk historisk materialismes sag. Men regningen kom, og den måtte komme. Og først da den kom i det tyvende århundredes andet årti (nærmere betegnet d. 2. august 1914), begyndte enheden i den internationale arbejderbevægelse at smuldre. Der havde ganske vist været ansatser til en venstreradikal kritik af socialdemokratiernes politik - Rosa Luxemburg og Lenin -, men det var stadig socialdemokrater, som leverede kritikken; det var stadig fraktionsstridigheder i en enhedsbevægelse. 
Det blev altså den kapitalistiske udviklings- og fremskridtsform i dens tilspidsede variant som krigsimperialisme, som skulle føre en virkelig splittelse ind i den internationale arbejderbevægelse. Splittelsen blev forberedt af arbejderklassens teoretikere under 1 . verdenskrig, medens klassen selv accepterede at lade sig tilsvine af mudder og blod på de europæiske slagmarker. Prisen for den politiske fejlforståelse af den lange fremgangslinje $\mathrm{i}$ årtierne før 1914 blev dyr. Efter at have levet med kapitalismens fremskridt, måtte man nu leve eller $\mathrm{d} \varnothing$ med dens modsætninger i disses yderste tilspidsede form. Men trods alt udviklede historiens bagside atter engang betingelserne for historiske nydannelser, i det hér tilfælde oktoberrevolutionen i Rusland, de revolutionære opstande i Tyskland og som international konsekvens heraf: en varig splittelse af den internationale arbejderbevægelse. På den ene side kommunistpartierne, på den anden side socialist- eller socialdemokratierne.

For i sammenhængen hér at gøre en meget langt og kompliceret historie kort fik dette følgende konsekvenser for den marxistiske videnskabelighed. I opbrudsfasen fra den internationale socialdemokratiske enhedsbevægelse og frem til splittelsens fuldbyrdelse ca. fra $1923 \mathrm{og}$ frem, blev der produceret meget betydelige marxistiske værker: Rosa Luxemburgs værker (især måske »Socialreform og revolution« samt skriftet »Om den russiske revolution«), Lenins politiske værker (frem for alt og af irreversibel betydning for en marxistisk teori: »Staten og revolutionen«) og endelig Trotskijs historiske værker - for helt stikordsagtigt at nævne de vigtigste. Trotskij er hér relativt unik sammen med Gramsci i Italien, fordi de ikke dør i selve denne opbrudsfase, men får et par årtier til at tænke dens resultater, muligheder og fejltagelser igennem. På den anden fløj, nemlig i socialdemokratierne, visner enhver teoretisk betydningsfuld indsats med basis i en marxistisk inspiration efterhånden bort. Dette sker som en konsekvens af partiernes pragmatiske accept af kapitalismens betingelser for klassekamp og proletarisk reproduktion. Otto Bauer, Hilferding og Kautsky er de sidste repræsentanter for den gamle socialdemokratisme, som endnu tænker under inspiration fra marxistiske (herunder marxsk-engelsske) teoripositioner, og de dør alle inden 2. verdenskrig.

Dette betyder ikke, at der ikke tænkes eller udvikles videnskabelighed fra socialdemokratisk hold, men det er ikke længere marxistisk intenderet videnskabelighed. Socialdemokratiernes integration i den borgerlige stat ofte som statsbærende parti - og dens integration i en borgerligt præget ideologi fører tværtimod til mange videnskabelige nydannelser: statsproblematikken fører til styringsvidenskab og socialkybernetik, og integrationen i borgerlige ideologemer fører til noget af den vigtigste og mest betydningsfulde moralfilosofiske nytænkning i dette århundrede (Gadamer, Apel, 
Habermas m.fl.). Dette rokker dog ikke ved tesen hér, nemlig at der ikke længere indeholdes noget utopisk perspektiv om et radikalt anderledes liv (end det kapitalistiske liv) i denne tænkning, og dette gør, at vi mener at kunne bestemme denne tænkning og videnskab som integreret i borgerlige aksiomer og paradigmer, dvs. som en (ikke uvæsentlig) del af borgerskabets ideologiske hegemoni.

Den socialdemokratisk inspirerede tænkning og videnskabelighed har ikke blot mistet det hegemoniale perspektiv eller den hegemoniale ideologiske og videnskabelige potens på dén måde, som det på forskellig vis bliver tilfældet for den partikommunistiske og den venstremarxistiske teoridannelse. Den socialdemokratiske tænkning og videnskabelighed er slet og ret blevet integreret i den borgerlige ideologi og den borgerlige videnskabeligheds historiske hegemoni. Som sådan repræsenterer den en vigtig bestanddel af nyere borgerlig teoriudvikling, og som sådan må dens erkendelser integreres i en potentielt hegemonial marxisme.

\section{(b) den defensive marxisme: venstremarxismen}

Efter 1923, hvor det er blevet klart, at der ikke bliver nogen revolution i vesten $\mathrm{i}$ denne omgang, skabes de virkelige nybrud i den marxistiske videnskabelighed fra positioner hinsides den fatale splittelse mellem kommunismen og socialdemokratismen. Det vil sige så meget som, at de skabes i politisk isolation fra arbejderbevægelsens to altdominerende politiske tendenser fra nu af. Vi kan sammenfatte denne tradition i betegnelsen venstremarxisme og gå over til at forsøge at karakterisere dens særlige kendetegn.

Splittelsen af den internationale arbejderbevægelse har betydet, at det ikke har været magtmæssigt muligt at føre noget europæisk land frem til et revolutionært brud med kapitalismen og borgerskabet igennem arbejderklassens overtagelse af produktionsmidler og magtapparater. Jeg ser bort fra folkedemokratierne østpå, da magtskiftene hér ikke har ført til den brede befolknings overtagelse, kritik og tilegnelse af livsbetingelserne. (Jugoslavien er muligvis en undtagelse). Magtmæssigt har arbejderbevægelsen altså været så splittet i sine to hovedtendenser, at det på så godt som intet tidspunkt har kunnet komme på programmet med et virkeligt revolutionært opgør med kapital og borgerskab. Arbejderklassens kultur har også ført en ret kummerlig tilværelse i hver af de to lejre, selv om den selvfølgelig er blevet fastholdt og endda udbygget på nogle områder, medens den er blevet nedbrudt på andre.

Men vi koncentrerer os hér om konsekvenserne for den marxistiske videnskabelighed, og disse er ikke få og ejheller uden fatale konsekvenser. 
Marxismen indenfor hver af de to lejre mister evnen til at syntetisere sine opdagelser; den mister evnen til at få øje på historiske nydannelser under kapitalismen i almindelighed, og under den aktuelle (sen)kapitalisme i særdeleshed; kort og godt: enhver videreudvikling af de epokegørende opdagelser i Marxs kritik af den politiske økonomi, enhver rekonstruktion af en kritisk historisk materialisme bliver umuliggjort. Det er næppe for meget sagt, at marxismen dermed mister sin videnskabelighed overhovedet og bliver til legitimationsvidenskab. Grundfejlen ligger i den manglende mulighed for at anskue de historiske processer under en syntetiserende synsvinkel. Det bliver på forhånd umuligt at søge efter een, mulig sandhed i historien. Alt går op i polemikkens hadske røg, og på den afbrændte slagmark får den borgerlige videnskabelighed igen sin chance. Sin chance for i det mindste bare at turde se, hvad der foregår - lad så dens forståelse af det være så ideologisk inficeret det være vil.

Dette forhold kan man beskrive mere eller mindre radikalt. Hvis man har interesse og fordel af at bøje sig for det internationale borgerskab, hvis mangel på ideologi stadig er et pres, kan man - som de nye franske filosoffer - føre sig frem med, at marxismen er en udlevet og konservativ idé fra det forrige århundrede. Dermed er selvfølgelig intet forstået, men det er jo heller ikke meningen. Nok er det at slå fast, at dén marxisme, som har regeret i de to lejre, de facto er blevet gjort konservativ af århundredets skammelige økonomisk-politiske udvikling. Den borgerlige videnskab har faktisk set mere i dette århundrede, end de dogmatiske eller reformistiske marxismer har. Men der har som sagt også været en tredje tradition i dette århundredes marxistiske tænkning, som vi passende kan gå over til at beskæftige os med.

Denne tradition er den venstremarxistiske teoritradition, og den tæller navne som Karl Korsch, den unge Georg Lukács, Frankfurterskolen, Jean-Paul Sartre og mange, mange flere. Det vigtigste er hér at få fat på betingelserne, hvorunder denne tradition fastholder og søger at videreudvikle den marxistiske videnskabelighed. Den første og altafgørende betingelse, som også markerer en hindring, er isolationen fra arbejderklassen og arbejderbevægelsens erfaringshorisont. Dette introducerer en elementær standpunktsforvirring i den marxistiske videnskabelighed, som var ukendt for Marx og Engels, og som også er ukendt i den socialdemokratiske såvel som den partikommunistiske lejr, hvor den dog betales med manglende evne til overhovedet at udvikle teorien (bl.a. fordi standpunktsforvirringen som et objektivt vilkår for tænkning i næsten hele dette århundrede fortrænges).

Selv om denne standpunktsforvirring er et objektivt vilkår for tænkningen i dette århundrede (inkl. den marxistiske tænkning) og derfor også sætter objektive skranker for denne, så får den ikke desto mindre en række 
definerbare konsekvenser for arten af venstremarxistisk teoriudvikling. For det første bliver denne i ekstrem grad filosofisk orienteret, hvilket også kan siges på en anden måde: af de borgerligt dominerede videnskaber får den marxistiske videnskabelighed allernådigst tildelt filosofiens smalle niche. Det betyder, at den marxistiske teori - selv når den qua venstremarxisme er mest potent og radikal - næsten altid reduceres til en slags tværvidenskabelig metadisciplin.

Det indicerer noget om arten af de udsagn, der kan rummes i en sådan teori, hvorfor det også indirekte indicerer noget om denne teoriforms grænser. Udsagnene er abstrakte, principielle og metodisk anlagt, og de har kun et ringe blik for differentia specifica; herunder specificiteter, der fostres af kapitalismens, hhv. senkapitalismens egen historiske dynamik, og som derfor burde være de genuine objekter for en kritisk rekonstrueret historisk materialisme. Inden vi går i detaljer med grænserne og hvordan de kan overskrides, så lad os dog opholde os et øjeblik ved de positive erkendelser, som kan vindes selv indenfor disse grænser.

Vi må dog vedføje, at den følgende karakteristik af venstremarxismen er en redegørelse for fællestræk ved en mangfoldighed af forskellige teoridannelser. Når det kan være meningsfuldt med en redegørelse for fællestræk på trods af de venstremarxistiske teoripositioners meget store indbyrdes forskellighed, beror det på dén historiske rekonstruktionsinteresse, som er styrende for fremstillingen.

Det må kunne konstateres, hvilke omkostninger, der har været forbundet med at udvikle marxistisk videnskabelighed i politisk og teoretisk isolation fra hovedstrømningerne i århundredet. Samtidig må der kunne holdes fast ved de erkendelser, der trods alt er nået, bl.a. fordi det har været en nederlagshistorie, man har isoleret sig fra for at kunne bevare og udvikle de momenter, som det har været muligt at udvikle så at sige under abstraktion fra nederlagene, fra borgerskabets hegemoni på alle områder. Kort sagt: hvad karakteriserer en marxisme i defensiven; en marxisme i defensiven, som selv i defensiven søger at fastholde nogle grundaksiomer fra Marx' og Engels' forfatterskab og den socialistiske tradition. At forsøge at skitsere disse fællestræk hører med i forarbejdet til en rekonstrueret, hegemonial marxisme. Dermed er det også sagt, at der i fremstillingen abstraheres fra de mange store og små forskelligheder indenfor denne tradition; forskelle, der i flere tilfælde - hvis der hér var tale om en teoretisk evaluering - måtte siges at være antagonistiske modsætninger og for så vidt umulige at bringe på den samme formel.

Det har været et så godt som gennemgående træk for alle venstremarxistiske positioner, at de har været i stand til at bryde med naturdialektikken i dens bastante form, og det har også været karakteristisk, at teoripositio- 
nerne på den ene eller den anden måde har kunnet tematisere det brudfyldte forhold mellem den første og den anden natur. Det er sket i yderst forskellige terminologiske gevandter, men det er så godt som altid sket: $\mathrm{i}$ den tidlige frankfurterskole sker det igennem at operere med netop begreberne om den første og den anden natur; hos Habermas er der en skelnen mellem instrumentel handlen og interaktionshandlen; hos Sartre er der en skelnen mellem analytisk fornuft og dialektisk fornuft - og man kunne blive ved. Indenfor den generelle filosofisk prægede diskussion, som man har deltaget i, er det med andre ord de historiefilosofiske problemstillinger, som har haft hovedvægten. Altså overvejelserne omkring, hvad den menneskelige historie er for noget, hvordan den forholder sig til sine naturgivne udgangsbetingelser etc., etc. Men selv hér må det høje generalitetsniveau konstateres, på hvilket denne diskussion er foregået, og en uddybende, konkretiserende forståelse af netop kapitalismens differentia specifica som produktionsmåde og verdenshistorisk epoke er det sjældent, for ikke at sige aldrig blevet til.

I den klassiske tyske idealisme kunne oplysningstidens generelle historieog fremskridtteori kun diskuteres på et hypergeneraliseret niveau, fordi den tyske virkelighed på daværende tidspunkt p.gr. af sin tilbagestående karakter ikke kunne levere konkret erkendelsesmateriale for en konkretiseret borgerlig historieteori. Det førte i begyndelsen (hos Kant og Schiller) til, at de historieteoretiske paradigmer blev taget op i et andet medium end deres eget, nemlig æstetikkens medium. Den tyske historie kunne ikke bibringe tyskerne nogen syntetiserende forståelse af den virkelige historie. Det kunne alene æstetikken og de æstetiske anskuelsesformer. Noget lignende har tilsyneladede gjort sig gældende for den venstremarxistiske videnskabelighed i dette århundrede. Man har drevet det temmelig vidt, hvad angår æstetiske overvejelser indenfor denne tradition. Litteraturen og kunsten blev til refugium for de kommunismeanticiperende forestillinger, som var fordrevet fra den virkelige historie - og af den virkelige historie.

Den venstremarxistiske position er hele vejen igennem en utopisk position i betydningen: en position, som utopiserer. Og det er ikke nogen tilfældighed, at det er een af traditionens vigtigste repræsentanter - nemlig Ernst Bloch -, som i kølvandet på netop 1. verdenskrig giver sig i lag med at rydde en plads for utopien i den marxistiske teori, efter at Engels som bekendt havde fors $\emptyset \mathrm{gt}$ at søge at uddrive utopien fra socialistisk tænkning i sin pjece om »Socialismens udvikling fra utopi til videnskab «.

Hvordan det nu end nærmere forholder sig med dette træk ved den venstremarxistiske tradition, så udtrykkes der i de vidtrækkende overvejelser af utopisk art også en mangel. En mangel - dels selvfølgelig i den virkelige 
historie (nemlig umuligheden af at sætte sig i forbindelse med een arbejderklasse/arbejderbevægelse), dels også den mangel, som udspringer af at teorien så godt som kun giver sig af med almene filosofiske og metodologiske problemer.

Af vidtrækkende betydning er også det bestandige pres fra de borgerlige videnskaber, som til stadighed betyder, at den marxistiske teori må legitimere sig og forsvare sin berettigelse selv i den snævre filosofiske niche, som den får lov at opholde sig i - ved siden af andre »videnskabsteorier«. Det vigtigste resultat af denne tradition er derfor også den utopiserende funktion, fastholdelsen ved muligheden af en radikalt anden samfundsmæssig og menneskelig tilstand. Fastholdelsen betyder, at der kan kritiseres udviklingstendenser og såkaldte fakta i den kapitalistiske historie, som ellers ville kunne have ligget uantastet hen i deres positivitet.

En virkelig teori-udvikling sker der dog knap nok, hvilket ytrer sig symptomalt i de mange eksempler på suppleringsstrategi. Fordi det anes i den venstremarxistiske fløj, at de historisk-materialistiske erkendelser i direkte forlængelse af den klassiske tradition, som man kan diske op med, er yderst spinkle og få, føles en nødvendighed af at supplere den magre historiske materialisme med andre, borgerligt udviklede videnskaber. Programmerne om at supplere den historiske materialisme med psykoanalysen (Reich, Marcuse etc.) eller med fænomenologien/eksistentialismen (Sartre, Kosik etc.) er velkendte, og de peger på, at man kun har kendskab til en mager historisk materialisme.

Samtidig ytrer der sig heri, hvilket vi allerede har strejfet, at de borgerlige videnskaber (f.eks. og måske nok især fænomenologien og psykoanalysen) de facto har fået øje på nogle af de kapitalistiske betingede, historiske nydannelser, som er blevet skabt og skabes i løbet af kapitalismens verdenshistoriske forløb. Lejrmarxismerne var som sagt blevet blinde overfor sådanne nydannelser, og venstremarxismen var i meget høj grad blevet trængt ud i det filosofiskmetodiske baglokale, og herfra kunne der kun halvt skimtes, hvad der virkeligt foregik - og oftest kunne man altså som sagt kun skimte dette via de borgerlige videnskabers analyser.

Opbruddene i den internationale arbejderbevægelse fra 1956 over 1968 (for nu at sætte årstal på) og frem er imidlertid i færd med at skabe betingelserne for en overskridelse af den triste situation, som marxismen (marxismerne) har befundet sig i det meste af dette århundrede. Socialdemokratierne er ikke længere socialistiske, og de er kun arbejderpartier i sociologisk-statistisk forstand, fordi historien indeholder en praktisk-træg dimension, som gør, at der stadig kan leves på resultater, som den socialdemokratiske arbejderbevægelse tilkæmpede sig i trediverne og et par årtier frem. Andelsboli- 
gerne fra halvtredserne står der stadig. Kommunistpartierne er også i skred, og de står foran (alt efter nation) enten at skrumpe ind til sekteriske smågrupper - og så er de ikke længere arbejderpartier, endsige folkelige bevægelser (dén vej synes det at gå i Danmark) -, eller også omdannes de indefra og bliver til nogle helt andre organisationer/organisationstyper end de var (dén vej kan det muligvis gå i Italien, Frankrig og andre steder). I denne opbrudsfase har de venstremarxistiske positioner også kunnet udvikle sig i positiv retning - integreret som de i høj grad har været i de sociale bevægelser, som er dukket frem de sidste tyve år, og som bedre end noget andet udtrykker, hvad der er på færde. Den vesttyske teoritradition i alle dens afskygninger fra midten af tresserne viser dette, selv om den i dag står i fare for at blive indkapslet i den universitære ghetto som en konsekvens af, at de sociale bevægelser, som var dens erfaringsbasis, er gået i coma i dagens Vesttyskland; centret frem for noget for en mulig fremtidskapitalisme. Althusserskolen viser det, og ledende althusserianere står i dag i spidsen for bestræbelserne på at omdanne det franske kommunistparti indefra; for at skabe dén nye og tidssvarende organisation/organisationstype, som kan blive resultatet af de igangværende opbrud, og om hvilken man kan spørge sig selv, hvorvidt det vil give nogen mening at kalde denne nye organisationstype for et parti i den klassiske betydning af ordet.

\section{Mod et nyt teoretisk hegemoni}

Vi kan nu med baggrund i denne historiske skitse gå over til at pege på nogle af de opgaver, som hænger sammen med at genvinde et historisk og teoretisk hegemoni for en ny marxisme, for en (re)konstrueret historisk materialisme. Der er peget på nogle betingelser for, at en sådan (re)konstruktion - et sådant hegemoni - er blevet historisk muligt. Lad os dog kort, inden vi kommer ind på nogle af de konkrete perspektiver, søge at klargøre, hvad der menes med et teoretisk hegemoni.

Central er hér under alle omstændigheder - ja, det er hovedpointen i hele denne artikel -, at et teoretisk hegemoni ikke er muligt uden i det mindste mulighederne for et historisk og magtmæssigt hegemoni. Når det er sagt, kan det også præciseres, hvad der menes med hegemoni. Hegemoni er at få greb om de historiske processer uden at fortrænge disses latente tendensindhold; uden at fortrænge dén historiske sandhed, som er i færd med at konstituere sig. Og teoretisk hegemoni er den erkendelsesmæssige (og for den evt. praktiske reali- 
sering: den begyndende) anticipation af en sådan frigørende bemestring af de historiske processer.

På det erkendelsesmæssige og videnskabsteoretiske felt må det (begykndende) historiske hegemoni udtrykke sig som den teoretiske marxismes (voksende) syntetisering og kritikpotens overfor den borgerlige videnskabelighed og tænkning. Når kritikken inkorporeres i en syntetiserende bevægelse, bliver der tale om hegemoni og ikke fortrængende, radikalistisk kritik. Radikalismen er netop tegn på, at der kritiseres ud fra en grundlæggende defensiv position.

Kritik og syntetisering må foregå samtidigt, og der må lægges afstand til den radikalistiske kritik, først og fremmest fordi denne ikke længere er historisk nødvendig. Når kommunismens utopier kan bringes sammen med den virkelige historie (: i kraft af kommunismens aktualitet), så kan kritikken af det borgerlige samfund blive syntetiserende, eftersom et andet og sandere samfund kan skimtes på det kapitalistiske samfunds bagside. Indoptagelsen af den borgerlige teori og videnskab i en marxistisk hegemonibestræbelse implicerer en differentiering i den foreliggende, borgerlige teorimasse, men det skal være en indoptagning, hvis perspektiv netop er hegemoniet. ${ }^{1}$ En sådan hegemonibestræbelse kan ikke føle sig forpligtet til i hvert enkelt tilfælde at redegøre for »ophævelsen « af dette eller hint begreb i den hegemoniale rekonstruktion. Den må tværtimod insistere på, at de anvendte begrebers eventuelle anvendelighed diskuteres på den hegemoniale bestræbelses betingelser og ikke på den ene eller den anden alvorsfulde borgerlige teorikonstruktions betingelser.

Et givet begreb er således - fra den hegemoniale bestræbelses synspunkt - ikke blevet uanvendeligt, fordi det ikke længere har præcis den samme betydning som i dets oprindelige sammenhæng. ${ }^{2}$ Tværtimod viser

1. Her refererer jeg implicite til en erfaring, vi gjorde under arbejdet med »Kapitalisme, behov og civilisation«. Ustandseligt dukkede begreber fra den borgerlige tænkning op i vores fors $\emptyset \mathrm{g}$ på at etablere et civilisationskritisk paradigme, men disse begreber blev aldrig styrende for de grundlæggende teser i arbejdet. Og det viste sig irrelevant at involvere sig i en immanent diskussion med de teoribygninger, hvorfra de for os anvendelige begreber dukkede op. Og spørgsmålet er, om arbejdet ikke ville have mistet sit hegemoniale sigte, hvis vi i jeg véd ikke hvilken alvorlig videnskabeligheds navn havde følt os forpligtet til en immanent redegørelse for forholdet til Kierkegaard, Foucault, Weber, Sartre ... Dermed har jeg selvfølgelig ikke sagt, at indoptagningen og syntetiseringen skulle være perfekt eller bare vellykket $\mathrm{i} \gg$ Kapitalisme, behov og civilisation «, men jeg har sagt, at begreberne dukkede organisk frem i arbejdet på at opstille det civilisationskritiske paradigme.

2. Når vi f.eks. i »Kapitalisme, behov og civilisation« taler om, at mennesket (i det moderne samfund) er karakteriseret ved »reflektivitet« eller ved at være »et forhold, der forholder sig til sig selv «, menes der noget ganske andet end Sartre og Kierkegaard, hvorfra betegnelserne stammer. Man kunne måske sige, at begreberne i radikal forstand har holdt flyttedag og er flyttet ind i et 
ser uforpligtetheden i forhold til begrebets oprindelige hjemsted, at der er tale om fors $\emptyset \mathrm{g}$ på hegemonisering.

Lad os så med disse korte metodiske stikord gå over til at pege på enkelte af de opgaver, som hegemonibestræbelserne står overfor.

I forhold til det enorme tekstkorpus, som vi finder i Marx's og Engels' skrifter, er den vigtigste opgave at efterspore kapitalismeforståelsen i kritikken af den politiske $\varnothing$ konomi. Og så vidt jeg kan skønne, må et sådant detektiv- og rekonstruktionsarbejde følge to hovedspor. Dels må kritikken af den politiske $\varnothing$ konomi afs $\varnothing$ ges for udsagn og implikationer vedrørende kapitalismen som verdenshistorisk epoke, og dette implicerer igen en undersøgelse af kapitalismens egne selvforståelsesformer, fordi disse selvfølgelig delvist altid er ideologisk inficerede, men også altid har fået øje på nogle af kapitalismens frembringelser af verdenshistorisk betydning. ${ }^{3}$ Dernæst må kritikken af den politiske økonomi afs øges for udsagn og implikationer vedrørende kapitalismens særlige, modsætningsfyldte karakter, som gør, at denne produktionsmåde peger ud over sig selv; at den er en endelig og ikke evig foreteelse.

Det er enheden af disse to momenter, der giver mening til tesen om kommunismens aktualitet. Kapitalismen udvikler i og af sig nogle irreversible kvaliteter, som den ikke selv kan fuldbyrde eller udvikle videre, og som derfor peger ud over kapitalismen. I lyset af tesen om kommunismens verdenshistoriske aktualitet må Marx’s og Engels’ skrifter gås efter i sømmene.

andet hus end dét, hvori de blev født. Dermed er det ikke sagt, at vores anvendelse af disse begreber er heldig, men det er sagt, at deres eventuelle uanvendelighed må påvises med baggrund $\mathrm{i}$ den hegemoniale bestræbelse og ikke med baggrund i, at vi anvender dem anderledes end Sartre og Kierkegaard gør. For dét er netop meningen.

3. Dermed kan det også angives, hvad vi i »Kapitalisme, behov og civilisation« mener med det civilisationskritiske paradigme. Vi udtaler os i den forbindelse ikke om den menneskelige civilisation i al almindelighed, men vi interesserer os for de civilisationsudviklende og civilisationsdestruktive kræfter i kapitalismen. Den civilisationskritiske interesse er ikke - som det er blevet hævdet - centreret omkring den vestlige civilisation af princip eller con amore, således forstået, at den finder en marxistisk beskæftigelse med andre civilisationsformer irrelevant. For eksempel med henblik på - i anticipationens interesse - at lære af andre eksistensformer og udviklingsforståelser end den vesterlandske. Tværtimod ligger der netop i det civilisationskritiske i beskæftigelsen med den vesterlandsk-kapitalistiske civilisation en, underforstået, opfordring til også at lade sig inspirere af andre civilisationsformer med henblik på forandringen af dén vesterlandske civilisationsform, der er ved at blive global og derfor umulig at komme uden om i en historisk-materialistisk kritik. På den anden side ligger der i bogen en insistering på, at den hegemoniale marxisme - af den kapitalistiske verdens globale rækkevidde - er henvist til at tage det grundlæggende, forståelsesmæssige og praktiske, opgør med udgangspunkt i den vestlige, men snart globale civilisationsform. Det er ikke os, der bestemmer kamppladsen, og kamppladsen er altså - på globalt plan efterhånden - den vestligt-kapitalistiske civilisationsform. 
Der kan i dag næppe heller herske tvivl om, at et sådant kritisk afsøgningsarbejde i Marx's og Engels' må føre til en intern tekstkritik. På en lang række punkter og især i deres programmatiske skrifter ligger Marx og Engels under for forståelsesformer, som ikke er kongruente med den forskningspraksis og faktiske dechiffreringsform, som vi ser udfoldet i kritikken af den politiske $\varnothing$ konomi. Disse forståelsesfigurer af programmatisk art må opspores og undersøges kritisk i lyset af den implicite, men desværre aldrig programmatisk udfoldede forståelse af kapitalismens væsen, som vi finder i kritikken af den politiske $\varnothing$ konomi.

Og dette arbejde er ikke blot et tekst-tilegnelsesarbejde. Det er faktisk også et teoretisk konstruktionsarbejde. Vi må nemlig for det første konstatere, at de programmatiske overbegreber fra den generaliserede historiske materialisme $\mathrm{i} »$ Den tyske ideologi« og hos den gamle Engels (produktivkræfter/produktionsforhold, basis/overbygning) rent faktisk ikke styrer forsknings- og fremstillingsformen i kritikken af den politiske $\varnothing$ konomi. Paradigmerne bag disse begreber må derfor opspores og gennemtænkes kritisk. Tentativt og som et første bud kunne man hér lancere den tese, at hovedparadigmerne i den generaliserede historiske materialisme er nye gennemspilninger af temaer fra den klassiske borgerlige oplysningstænkning. Sagt ultrakort kunne man hævde, at disse fremstillinger ligger under for to falske paradigmer fra denne tradition, nemlig linearitets- og nødvendighedsparadigmet, hvad angår historisk udvikling og fremskridt. Menneskehedens historie udvikler sig i en lang lineær fremskridtslinie, og der består logiske nødvendighedsrelationer mellem de enkelte faser i denne udvikling (lad så iøvrigt denne logik være dialektisk, successiv - altså kausal eller noget helt tredie). Sådan lyder i al korthed dette paradigme, som det er muligt at kritisere fundamentalt med baggrund i kapitalismeforståelsen i kritikken af den politiske $\varnothing$ konomi.

Lyset, i hvilket disse paradigmer kan og skal kritiseres, er lyset fra tesen om kommunismens verdenshistoriske aktualitet. Den historiske dialektik mellem nødvendighedens og frihedens rige og den hermed paralleltløbende historiske dialektik mellem den første og den anden natur bryder fundamentalt med disse paradigmers gyldighed og relevans. Derfor hører kritikken af disse paradigmer sammen med den fors $\emptyset$ gsvise opstilling af andre og sandere paradigmer; derfor hører kritikken af den generaliserede historiske materialisme sammen med rekonstruktionen af en kritisk historisk materialisme.

Med i arbejdet for at (re)konstruere en historisk materialisme hører også livtaget med den borgerlige videnskabelighed. Det er grunden til, at vi kan sætte den lidt kunstlede parantes om (re) i rekonstruere. I et vist omfang er der tale om konstruktionsarbejde, idet andre og nye begreber må prøves. Marx og Engels har jo som sagt ikke selv udfoldet de civilisationshistoriske og civili- 
sationskritiske dimensioner i kritikken af den politiske økonomi, som vi også kan kalde momenterne i denne, som må være af umiddelbar relevans for rekonstruktionen af den kritiske historiske materialisme. Og marxismerne har været blinde stort set siden Marx og Engels - af historisk forståelige grunde, som vi har været inde på. Derfor må en aktuel marxisme gå i virkelig clinch med den borgerlige videnskabelighed, og kun derved kan den genvinde en hegemonial status i forhold til denne.

Det betyder bl.a. - og på det programmatiske niveau -, at suppleringsstrategierne må opgives i og med at de begribes historisk. Der er ikke noget permanent hul i marxismen (med Sartres rammende betegnelse), som skal stoppes ud med eksistentialisme, psykoanalyse eller noget helt tredie. Når der historisk har været dette hul, hænger det netop sammen med denne histories skammelige art, og hvad Sartre kalder for et hul i marxismen er i virkeligheden det faktum, at marxismen er blevet fravristet sin hegemoniale status i teorien, og at dette har sin afgørende grund i den nævnte skammelige historie. Marxismen er faktisk blevet gjort blind, og de borgerlige videnskaber har set mere end den. Psykoanalysen og fænomenologien har set udviklingsdimensioner, som marxismen ikke har kunnet se, i det sidste århundrede.

At genvinde marxismens hegemoniale status hænger derfor også sammen med at lære, at tage ved lære af de borgerlige videnskaber og teoridannelser. Men det skal altid ske kritisk og i lyset af arbejdet med rekonstruktionen af en kritisk historisk materialisme; og tesen er altså også hér af overvejende historisk karakter: denne kritiske tilegnelse KAN i dag finde sted under et tiltagende hegemoni fra den spirende historiske materialismes side. Der vil være tale om en stadig differentieringspraksis, i hvilken de relevante borgerlige videnskabers selvforståelsesformer kan kritiseres samtidig med at deres substantielle historiske indhold kan tilegnes. Sådan gjorde Marx også ved Hegels dialektik, og han gjorde det også suverænt - ud fra en hegemonial position. Så suverænt at det den dag i dag kan diskuteres, hvorvidt fremstillingen i kritikken af den politiske $\varnothing$ konomi faktisk er hegeliansk eller antihegeliansk. En diskussion, som ret beset er lidt meningsløs og hører hjemme i de betingelser, hvorunder teoriudviklingen måtte foregå i den skammelige histories århundrede (for nu at være patetisk!). Sikkert er det, at Marx aldrig projicerede nogen invariant hegelsk metode på den politiske økonomis materiale. Hegel blev integreret helt og aldeles i arbejdet med kritikken af den politiske $\varnothing$ konomi, og det var muligt på grund af kritikken af den politiske $\emptyset$ konomis hegemoniale teoretiske status overfor den borgerlige videnskab og ideologi. Hvorvidt Hegel helt forsvandt i denne proces eller ej, kan man derfor roligt overlade til fagpedanternes institutionaliserede tidsfordriv i dag, (hvor diskussionen tidligere kunne være berettiget, fordi den var integreret $\mathrm{i}$ 
det mere omfattende arbejde med selve karakteren af kritikken af den politiske $\varnothing$ konomies omgangslogiske status etc.).

Tilegnelsen og kritikken af den borgerlige videnskabelighed foregår, således forstået, som en bestræbelse på at tilegne og kritisere de historiske nova, som kapitalismen frembringer og har frembragt (som verdenshistorisk epoke). Dette arbejde kræver også konstruktiv begrebsfantasi. Ud over at begreber i et vist omfang kan lånes fra den borgerlige videnskabelighed, der jo ikke har været så blændet som marxismen, må der konstrueres nye begreber. Marx har jo som bekendt ikke udfoldet de civilisationsteoretiske og civilisationskritiske dimensioner i kritikken af den politiske $\varnothing$ konomi; for så vidt ligger disse dimensioner som implikater i og af kritikken af den politiske økonomi, der må udvikles - og stilles til diskussion.

\section{Til sidst et eksempel: Forholdet mellem stat og sam- fund OG forholdet mellem parti og bevægelse}

Der ligger i kritikken af den politiske økonomis kapitalismeanalyse kimformer til en anderledes og subversiv forståelse af klassiske diskussioner (både i den borgerlige oplysningsbetænkning og i den marxistiske teoritradition) om forholdet mellem stat og samfund, samt om forholdet mellem parti og bevægelser. Nøglebegrebet er samfundsmæssiggørelse - eet begreb, der kan retvende de klassiske diskussioner, fordi det er et proces- og tendensbegreb.

Samfundsmæssiggørelsen udspiller sig i tendensfeltet mellem staten og det enkelte, atomiserede borgerlige individ, og det indeholder en overskridende og ophævende effekt på de poler (stat og individ), som i første omgang kan være med til at definere den. Samfundsmæssiggørelsen trækker staten tilbage mod den enkelte og den enkelte op imod det samfundsmæssige, det kollektive. Derfor indeholder samfundsmæssiggørelsen som analytisk kategori og som tendensbestemmelse i virkeligheden en strøm imod staten og også imod statens logik.

Samfundsmæssiggørelsen indeholder for så vidt en tendens mod at pluralisere virkeligheden ved at gøre den bevægelig og dermed ophæve det statiske ved staten(s logik) og det borgerlige individatom. Og med pluraliseringen forløber også decentreringen - ikke som en moralsk viljesproces som i den denkoratiske centralisme, men som en faktisk spredning af magtcentre og indflydelsessfærer. Magtcentre og indflydelsessfærer, hvor det i højere og højere 
grad er samfundsmæssige individer, som handler, end det er abstrakte og alene repræsentative individatomer.

Det borgerlige samfund har skabt muligheden for sådanne nye alternativer, men det blokerer samtidig disse - ved at fastholde og insistere på det borgerlige individatom, og ved at fastholde og insistere på den borgerlige stats monolitiske og hierarkiske struktur. Derfor er den socialistiske bevægelse og den socialistiske tænkning også alene om at kunne anfægte denne borgerlige orden - bl.a. ved at gribe anticiperende an til tendensbestemmelser, som allerede er udviklet under kapitalismen. Til gengæld er det også nødvendigt at der gribes fat om disse realutopiske chancer, som kapitalismen har udviklet, for at føre verdenshistorien frem til virkelige og befriende nyskabelser for menneskeheden.

Ellers stivner også modbevægelsen i en gentagelse af dén orden, der revolteres imod, og hvis det bliver tilfældet, kan det hele også være lige meget - som nihilisterne siger. Men mellem disse to identiske poler findes chancen for et virkeligt brud, og til dette hører udviklingen af den hegemoniale marxisme. 


\section{NYHED!}

\section{LARS QVORTRUP}

\section{KRISE, REVOLUTION OG UTOPI}

Kriseteori - det begreb har efterhånden fået en snæver, økonomisk og pessimistisk klang: konjunkturnedgang, underskud på betalingsbalancen, strukturproblemer ...

Denne bog står på to måder i modsætning til den herskende »marxisme« på venstrefløjen.

Det er efterhånden - også på venstrefløjen - blevet et udbredt udsagn, at kapitalismen ikke nødvendigvis, dvs. på grund af indre lovmæssigheder, vil bryde sammen. Heroverfor fastholder bogen i en omhyggelig rekonstruktion af loven om profitratens faldende tendens og $i$ en kritik af forskellige forvanskninger af denne lov, at og hvordan kapitalismen $e r$ en sammenbrudsmærket produktionsmåde.

Det er efterhånden blevet et udbredt udsagn, at Marx's kriseteori handler om $\varnothing$ konomi i snæver forstand. Heroverfor fastholder bogen, at kriseteorien er en omfattende og forhåbningsfuld teori om sociale forhold: om kapitalismens klassekampe, om oprør, revolutioner og contra-revolutioner og om utopierne om et bedre samfund.

Kapitalismen bryder ikke bare sammen. Den afsætter også utopier om det klasseløse samfund som frihedens rige og den skaber mulighederne for virkeliggørelsen af et sådant samfund.

BOGLADEPRIS: 69,- KR

PRIS SOM KURASJE-ABONNEMENT 54,- KR 